\title{
Shanghai: Urban Planning Styles in Evolution.
}

Emergence of a "Harmonious Urbanisation"?

\section{Nicolas Douay}

\section{(2) OpenEdition}

\section{Journals}

Electronic version

URL: http://journals.openedition.org/chinaperspectives/4731

DOI: 10.4000/chinaperspectives.4731

ISSN: 1996-4617

\section{Publisher}

Centre d'étude français sur la Chine contemporaine

\section{Printed version}

Date of publication: 1 December 2008

Number of pages: 16-25

ISSN: 2070-3449

\section{Electronic reference}

Nicolas Douay, "Shanghai: Urban Planning Styles in Evolution. », China Perspectives [Online], 2008/4 | 2008, Online since 01 December 2011, connection on 28 October 2019. URL : http://

journals.openedition.org/chinaperspectives/4731; DOI : 10.4000/chinaperspectives.4731

(C) All rights reserved 




\section{Shanghai: Urban Planning}

Styles in Evolution

Emergence of a "harmonious urbanisation"?

NICOLAS DOUAY

Since the 1950s, Shanghai has undergone major changes, reflected in the practice of urban planning, which has been influenced by different Western theories. Strategic and collaborative currents as well as the concept of sustainable development have helped reformulate urban planning styles. Does this renewal mean the emergence of an original model of Chinese urban planning, notably with the concept of harmonious urbanisation?

$\mathrm{T}$ he rural exodus has caused Chinese cities to swell from 77 million inhabitants in 1953 to 190 million in 1980 , to 470 million in 2000 , and to 650 million today, if the floating population of some 150 million migrant workers in included. The spatial and demographic dimensions of the urbanisation phenomenon pose challenges to the practice of urban planning. Already 246 new cities have been built since 1990, and 400 more are expected to emerge by 2020 .

This article aims to identify the evolution of urban planning styles since the start of the twentieth century and specifically in the last five decades in response to the demands and stages of the urbanisation process. The hypothesis here is that China's situation is not much different from the western world's in matters of urban planning, and that its theoretical influences have been similar to those of other countries. The effort is to question the reality of changes in the practice of town planning with a special look at the strategic, collaborative, and sustainability currents at play. This questioning process leads on to the formulation and application of the concept of harmonious urbanisation, which appeared recently and is now presented as a new Chinese paradigm of urban planning.

The questions will be dealt with based on the case of Shanghai. Strategically located on the Chinese coastal belt at the mouth of the Yangtze River, Shanghai rapidly became a centre of major economic exchange. After the Opium War, different foreign occupying forces influenced town planning in this metropolis. Since the1950s, Shanghai has witnessed many changes ${ }^{(1)}$ reflected in the practice of urban development. These evolutions have taken different forms and help illustrate the theoretical and practical renewal in the field of Chinese urban planning. ${ }^{(2)}$
The article begins with a presentation of the traditional planning model, then considers strategic and collaborative influences before examining whether a new Chinese approach is emerging with the concept of harmonious urbanisation.

\section{Traditional Chinese planning}

\section{Influence of the rational model in response to the needs of modernisation}

Chinese urban planning has had several theoretical influences. ${ }^{(3)}$ Chinese philosophical tradition, including Confucianism and Daoism, makes up the oldest influence, but the West has also been a source of inspiration for the theories and practice of planning.

Ever since the end of the nineteenth century, the western world has developed a rational model of planning. Thus by the start of the twentieth century, in the context of industrial revolution, the doctrine of comprehensive planning emerged and became the dominant model. The structuring of this rational approach owes greatly to the work developed in the Chicago school during the 1940s and 1950s. ${ }^{(4)}$ This research was influenced by the Great Depression of the 1930s and the response of planners who proposed the New Deal; the Second World War then led to a strengthening of pub-

1. Marie-Claire Bergère, Histoire de Shanghai, Paris, Fayard, 2002.

2. Aprodicio A. Laquian (ed.), Beyond Metropolis: The Planning and Governance of Asia's Mega-Urban Regions, Washington DC, Woodrow Wilson Center Press, 2005.

3. Tingwei Zhang, Developing the Chinese Planning Theory - Planning Theory in the Age of Diversity, ACSP - AESOP, Conference paper, Chicago, 2008. Daniel B. Abramson, "Urban Planning in China, Continuity and Change," in Journal of American Planning Association, vol. 72, n²2, 2006, pp. 197-215.

4. Philip Allmendinger, Planning Theory, New-York, Palgrave, 2002. 
Evolution of metropolitan planning between 1959 and 1995

lic intervention in economic planning. With a multidisciplinary perspective, the Chicago school suggested the development of rational approaches to the entirety of public policies, including planning. ${ }^{(5)}$ From the 1950s a new scientific yardstick emerged, that of modernism. In planning, this meant the advent of rational-global planning, which soon took hold as the dominant paradigm in planning theory and also in professional practice. ${ }^{(6)}$

This model was also adopted in China by the $\mathrm{Na}$ tionalists, who pursued a policy of urban modernisation. ${ }^{(7)}$ When the Communists seized power, planning practices continued to closely follow the Western model. Beginning in the 1950s, town planning was thus influenced by socialist theory, with Soviet-inspired centralism and planning committees, as well as waves of industrialisation and nationalisation in the 1950s and 1960s. In the socialist context, urban planning is not meant to control and lead economic development as in the case of a market economy. Rather, it is meant to localise state projects and embody the government's grand policy aims. ${ }^{(8)}$

The advent of communism focused Chinese urban planning on the aims of urban modernisation with an effort to develop industry. Nationalisation of private enterprises in 1956, along with major state investments, helped sustain this strategy. Shanghai's town planning followed the aims of industrial growth with the creation of zones confined to such activity. Urban policies thus tended to maximise industrial production using existing urban space while supporting the development of new projects. Finally, the Cultural Revolution was a major turning point. Mao Zedong strengthened his rhetoric against cities, which translated into a total rejection of urban planning between 1966 and 1976.

\section{Closed arena for elaboration of plans}

In practice, traditional Chinese urban planning created two models ${ }^{(9)}$ : The classical top-down approach of the "emperor ruling," and that of socialist centralised planning, or "big government." In this context, major decisions as well as the regulation mechanism of society were decided at the central level, while municipal officials had little influence over the form and content of urban development.

In the classical model of Chinese planning the only interaction is among traditional actors, namely the political leadership and the planners who act as experts. Even if the ideal of this socialist practice of town planning is to "serve the people," in practice this style of town planning is highly bu- reaucratic: the elaboration of plans is merely a technical issue sorted out between experts and political elites, without opening the arena to outside influences.

\section{Strategies centred on regulating land use}

In the West, traditional urban planning has these basic values: scientific knowledge and expertise, especially regarding necessary information (statistical and cartographic). The aim of this rational model is to serve the public interest. ${ }^{(10)}$ This model is dominated by a spatial approach aimed at regulating land use. It was developed in the West in the context of the " 30 glorious years" of fast growth in the postwar period and was concerned with regulating growth by zoning and building density, through collective projects... To realise these ambitions, this traditional model focused on producing plans.

In Shanghai the great revolution had an important influence on urban development, resulting in the construction of numerous infrastructural projects as well as industrial zones in the suburbs and outlying areas. In the 1950s, urban planning advanced the reinforcement of industrial areas close to agglomerations such as Pengpu or Dachang in the north or Taopu in the west. ${ }^{(11)}$ The adoption in December 1958 of

5. Martin M. Meyerson et al, Politics, Planning and the Public Interest: The Case of Public Housing in Chicago, New York, Free Press, 1955.

6. John Friedmann, Planning in the Public Domain, Princeton, Princeton University Press, 1987. Charles E. Lindblom, Inquiry and Change: The Troubled Attempt to Understand and Shape Society, New-Haven, Yale University Press, 1990

7. Michael Tsin, "Canton Remapped," in J. W. Esherick (ed.), Remaking the Chinese City: Modernity and National Identity, 1900-1950, Honolulu, University of Hawaii, pp. 19-29.

8. Fulong Wu, "The Global and Local Dimensions of Place-making: Remaking Shanghai as a World City," in Urban Studies, vol. 37, n8, 2000, pp. 1359-1377.

9. Zhang, 2008, art. cit.

10. Meyerson, 1955, op. cit.

11. Marie-Claire Bergère, "Shanghai's Urban Development: A Remake?" in S. Kuan et al., Shanghai - Architecture \& Urbanism for Modern China, Munich, Prestel, 2004, pp. 36-53. 
an urban plan helped give another dimension to this strategy. Under British influence, the Shanghai authorities decided to build satellite towns in a green belt about 20 to $70 \mathrm{~km}$ from the city centre. To sustain the aim of industrialisation, many works projects helped to establish new industries in the outlying areas at a distance from the city centre in order to integrate them with new housing projects. Moreover, the satellite towns help reduce congestion in central Shanghai.

In the West today, with difficulties in regulating land use have caused this practice of urban planning to be replaced by new approaches, but the issues raised by the rational model are still current. ${ }^{(12)}$ In the context of metropolitan Shanghai's fast growth, there is major interest in this spatial approach to town planning, as can be seen from the 1986 "Urban Master Plan of Shanghai Municipality" or the more recent "Plan of Shanghai Metro-Region" of 1995, which is based on the satellite town concept. ${ }^{(13)}$

In current practice, there is renewed debate over, for instance, applying the concept of polycentrism, but the process and content developed are part of the historical tradition. However, it is possible to discern the changes with the influence of different theoretical currents on planning as the strategic approach.

\section{Strategic influence: Shanghai's metropolisation}

\section{Strategic planning to meet the challenges of globalisation and international compe- tition among cities}

The notion of strategic planning is quite old. It originated in the military domain to help implement strategy, especially in the context of war. It was then appropriated by the business world to rationalise its activity. Finally, the public sector followed the same aim of rationalisation to achieve greater efficiency. As neo-liberalism took hold worldwide ${ }^{(14)}$ from the 1980s, strategic planning enjoyed general growth in the West and was applied in development and town planning. The strategic model marks a break from the traditional one by focusing public action on the search for results through the adoption of precise actions. In this perspective, the quest for efficiency through the realisation of projects seems to be the basic value of these strategic moves. ${ }^{(15)}$

From a more concrete point of view, this focus on action and results also shows an adaptation to the context of crisis in public finance in the West: "Mobilisation and articulation of resources become central issues of urban public action, which tend to determine the discussion on the action's very aims. The project then becomes the instrument that facilitates a permanent dialogue between a constantly evolving stock of resources and the always precarious and changing aims." ${ }^{(16)}$

In the Chinese context, the strategic influence can be traced back to the process of opening up that began with the end of Maoism. From 1979, four special economic zones were created. Along with other coastal cities, Shanghai received special attention. In order to boost economic activity, several special economic and technological development zones were opened (including Hongqiao, Minhang, and Caohejing). These efforts were followed by "socialist market economy." Cities are at the heart of this ambition, becoming the engines of the country's economic growth.

China's opening also corresponded with the general trend toward globalisation. This was accompanied by a series of territorial restructuring activities ${ }^{(17)}$ that increased the importance of the largest cities, especially those in the coastal region. This metropolisation phenomenon is generally seen as a movement with two parts. ${ }^{(18)}$ The first mostly concerns the internal process of structuring urbanisation under the effect of localisation strategies toward households and firms. It leads to a spread of urbanisation and to new territorial specialisations and new centralities. Shanghai has not escaped this spatial restructuring, giving rise to a three-speed city. ${ }^{(19)}$ The central part has undergone renewal with the refurbishing of the Bund, for instance, and of new rapidly developing areas such

12. Ernest R. Alexander, "After Rationality, What? A Review of Responses to Paradigm Breakdown," in Journal of American Planning Association, vol. 50, n¹, 1984, pp. 62-69.

13. Peter G. Rowe, "Privation to Predominance: Shanghai's Recent Rapid Resurgence," in S. Kuan et al., Shanghai - Architecture \& Urbanism for Modern China., Munich, Prestel, 2004, pp. 54-67. Shaoling Zhang, "Study on Shanghai's Spatial Structure for Further Urban Development," in China City Planning Review, vol. 16, n²2, 2007, pp. 24-39.

14. Bruno Jobert (ed.), Le tournant néo-liberal en Europe: Idées et recettes dans les pratiques gouvernementales, (Neo-liberal trend in Europe: Ideas and prescriptions in governmental practices), Paris, L'Harmattan, 1994.

15. Jean-Gustave Padioleau et al., "Les démarches stratégiques de planification des villes" (Strategic steps in planning of cities), in Annales de la recherche urbaine, vol. 51, 1989, pp. 28-39.

16. Gilles Pinson, "Le projet urbain comme instrument d'action publique" (Urban project as instrument of public action), in P. Lascoumes et al., Gouverner par les instruments (Governing by instruments), Paris, Presses de Sciences Po, 2005, pp.199-233.

17. John Friedmann, China's Urban Transition, Minneapolis, University of Minnesota Press, 2005.

18. Allen J. Scott, Global City-Regions: Trends, Theory, Policy, Oxford, Oxford University Press, 2001. Michael Storper, The Regional World: Territorial Development in a Global Economy, New York, The Guilford Press, 1997. Pierre Veltz, Mondialisation, Villes et Territoires: L'économie d'archipel, (Globalisation, cities and territories: Archipelago economy) Paris, Presses universitaires de France, 1996.

19. Jacques Donzelot, "La ville à trois vitesses: Relégation, périurbanisation, gentrification" (Three-speed city: Relegation, periurbanisation, gentrification), in Esprit, March 2004. 
as the Pudong New Zone, covering $522 \mathrm{~km}^{2}$. At the same time, other parts of the city have been largely ignored. ${ }^{(20)}$ The second part of metropolisation is more global and is predicated on the development of a system of metropolises in the economic context of generalised competition. This binary globalisation-metropolisation ultimately constitutes the essence of the great change taking place in today's cities.

China's metropolisation underlines the presence of three major cities ${ }^{(21)}$ that reach out to the world and aspire to world city status. ${ }^{(22)}$ Firstly, there is Hong Kong, which built on its status as a British colony to garner a prominent position with its financial as well as logistic activities, ${ }^{(23)}$ then Beijing, with its position as the capital and through its recent hosting of the 2008 Olympic Games, and finally Shanghai, which is one of the government's windows to the outside world. In this international competition between the world's largest cities, Shanghai's marketing strategy is based on organising a major event, namely the Universal Exposition of 2010. On the same level as the 2008 Olympiad, this event symbolises China's further opening up to the world. Expo 2010 will be held from 1 May to 31 October 2010 under the theme Better City, Better Life. More than 170 countries will take part, and more than 70 million people, mostly from within China, are expected to attend.

\section{opening to private actors and establishing a socialist pro-growth coalition}

As for spatial planning, the strategic model takes note of the passage to a neo-liberal referential by opening out to private actors, and consequently is not limited to the planner-decider duality. The economic world thus finds itself associated with the elaboration of the contents of planning, but above all to the implementation of strategies through the intermediaries of public-private partnerships (for both the investment process and also the management of urban services).

Since the start of economic reforms, the ever-present advertising in public spaces has symbolised Shanghai's modernisation. Major multinationals such as McDonalds, Pepsi, Visa, and KFC testify to the role played by foreign investment in the city's dynamic. The theories of urban regimes ${ }^{(24)}$ and of growth coalitions ${ }^{(25)}$ advance the idea that governance of cities is often characterised by an arrangement between public and private actors in order to facilitate economic growth. While these analyses emerged in the case of American cities, it seems pertinent to ask whether they apply to Shanghai. In a socialist context where the public sector makes up the major part of political and economic resources,
Tingwei Zhang has put forward the notion of a socialist progrowth coalition: "Shanghai reveals the characteristics of a socialist regime featuring successful government intervention, active business cooperation, limited community participation, and uneven distribution of benefits and costs of new developments." (26)

Organising Expo 2010 is one of the aims of this socialist pro-growth coalition. Shanghai retains leadership of the operation while interacting with private actors within China and from abroad. The decision-making is open and tends towards a public-private partnership. With total investment for Expo 2010 estimated at $\$ 3$ billion, 43 percent will come from government sources, 36 percent from private firms and 21 percent from banks.

\section{Architecture stars and major projects for a new skyline}

The strategic model calls into question the physio-spatial approach to planning and leads to an overturning of the plan concept with regard to the project. This model has the advantage of being flexible and able to adapt quickly to both the economic and political contexts by adopting a global vision that is also targeted. This type of planning is thus often focused on the realisation of special projects (transport infrastructures, special districts for economic and social development, or environmental protection, structuring equipment...) by insisting in particular on the notion of network, which exploits some territorial logic or stakes.

Further, from the perspective of competition between metropolises, there is generalisation of urban marketing strategies. ${ }^{(27)}$ In this sense, Expo 2010 is a tool whose international nature helps put Shanghai on the map of the world's

20. Tingwei Zhang, "Urban Development Patterns in China: New, Renewed, and Ignored Urban Spaces," in Song Yan et al., Urbanization in China: Critical Issues in an Era of Rapid Growth, Cambridge, Lincoln Institute of Land Policy, 2007, pp. 3-27.

21. Thierry Sanjuan, Atlas de la Chine: Les mutations accélérées, (China atlas: Accelerated change) Paris, Autrement, 2007.

22. Saskia Sassen, Global City: New York, London, Tokyo, Princeton, Princeton University Press, 1991.

23. Thierry Sanjuan, À l'ombre de Hong Kong: Le delta de la rivière des perles, (In Hong Kong's shadow: The Pearl River Delta) Paris, L'Harmattan, 1997.

24. Clarence Stone, Regime Politics: Governing Atlanta (1946-1988), Lawrence, Kansas University Press, 1989.

25. Harvey Molotch, "The City as a Growth Machine: Toward a Political Economy of Place," in American Journal of Sociology, vol. 82, n², 1976, pp. 309-332.

26. Tingwei Zhang, "Urban Development and a Socialist Pro-growth Coalition in Shanghai," in Urban Affairs Review, vol. 37, n4, 2002, pp. 475-499.

27. Nicolas Douay et al., "Glamour Planning, Designing Metropolis beyond Urban Marketing," in Nicolas Buchoud, Strategic City: Planners for the twenty-first century, Lyon, Éditions du CERTU, 2008, pp. 145-153. 

trend are different: they emerged in line with social movement theories and were formalised in the field of territorial planning from the 1990s onwards as part of the advent of a greater pluralism in society as it opened to new actors. Contrary to the post-modern current, the collaborative approach proposes to renew planning through communication. From a more theoretical point of view under the strong influence of the works of Jurgen Habermas, ${ }^{(32)}$ communicational action is important. It is defined as an interactive activity oriented towards understanding and seeking coordination of the implementation plans among partners.

The aim of collaborative planning is to achieve consensus through positive interaction in a large gathering of actors:

In the ideal of collaborative planning, stakeholders representing the differing interests meet for face-toface dialogue and collectively work out a strategy to address a shared problem. Participants work through joint fact finding and agree on a problem, mission, and actions. The players learn and co-evolve. Under the right conditions, this dialogue can produce results that are more than the sum of the parts. ${ }^{(33)}$

\section{NIMBY syndrome in the Maglev project}

The magnetic levitation train linking Shanghai's international airport to the city is the world's best known commercial operation of the German technology, which uses magnetic levitation to achieve a speed of $400 \mathrm{~km} / \mathrm{h}$. Construction work began in March 2001, and the line was opened in 2004.

Several extension plans for the network were proposed, and in January 2006 the municipality presented the project for a new line linking the international airport at Hongqiao with Pudong, the south-central station, the site of Expo 2010 and a connection to Hangzhou City in Zhejiang Province. This extension plan received government approval in February 2006 with the objective of realisation by 2010 . However, this apparently rational scheme adhering to a traditional planning approach has met with scepticism. In fact, affected residents staged several protests, pushing back and threatening to mothball the project, estimated to cost 35 billion Yuan (3.7 billion euros).

Thousands of people joined hands to denounce the project, with worries voiced on two counts. On the one hand were dangers to public health. While the cautious rules for this new technology call for an insulating green belt of at least 150 metres, the authorities had provided for no more than a 20-metre gap between the line and resi- dences, and residents feared the risk of radiation. On the other hand, protesters also feared the possibility of a decrease in the value of their property following the Maglev line's construction. The mobilisation can be compared with movements such as NIMBY ${ }^{(34)}$ (not in my backyard). ${ }^{(35)}$

\section{Beyond NIMBY: From protest to negotiation?}

Collaborative approach stems from the communicational current ${ }^{(36)}$ and underlines communication strategies to be followed in order to establish a positive interaction between the actors. In a context of uncertainty and conflict, as in the Maglev case, there is a great need to negotiate understanding among the participants representing different interests, leading to a compromise:

When there are multiple goals, (...) planning requires bargaining or mediation (...) When the means for accomplishing goals are also uncertain, (...) then adaptive approaches are needed to facilitate learning by doing. When both goals and means are uncertain, (...) charismatic leadership or a social learning strategy is needed. Only when society knows how to do a task and agrees on a single objective is top-down regulation appropriate. ${ }^{(37)}$

31. Pierre Hamel, "Crise de la rationalité: le modèle de la planification rationnelle et les rapports entre connaissance et action" (Crisis of rationality: rational planning model and the relations between knowledge and action), in $\mathrm{R}$. Tessier et al., La recherche sociale en environnement: Nouveaux paradigmes, (Social research in environment: New paradigms), Montréal, Presses de l'Université de Montréal, 1996, pp. 61-74.

32. Jürgen Habermas, The Theory of Communicative Action, Reason and the Rationalization of Society, Boston, Beacon Press, 1984. Jürgen Habermas, The Theory of Communicative Action, Lifeworld and System: A Critique of Functionalist Reason, Boston, Beacon Press, 1987.

33. Judith E. Innes et al., "Planning Styles in Conflict, The Metropolitan Transportation Commission," in Journal of the American Planning Association, vol. 71, n², 2005, pp. 177-188.

34. Denis J. Brion, Essential Industry and the NIMBY Phenomenon, Westport, Greenwood Pub Group, 1991.

35. This expression appeared in the United States to describe a new type of protest by residents opposed to airport and nuclear plant projects. It was highly succesful and inspired others such as the humorous sounding BANANA (Build Absolutely Nothing Anywhere Near Anyone) and LULU (Locally Unwanted Land Uses), NIMEY (Not In My Election Year), noting official prudence ahead of elections, and (Not On Our Street) reflecting microlocal opposition

36. Pierre Hamel, "La critique post-moderne et le courant communicationnel au sein des théories de la planification: une rencontre difficile" (Post-modern criticism and the communication current in planning theories: a difficult encounter), in Les Cahiers de géographie du Québec, vol. 41, n¹14, 1997, pp. 311-322.

37. Judith E. Innes, "Group Process and the Social Construction of Growth Management: Florida, Vermont and New Jersey," in Journal of the American Planning Association, vol. $58, n^{\circ} 4,1992$, pp. 430-453. 
Thus planning has to engender a collective process undertaken with the help of dialogue and exchanges among the actors. This continuous collective learning process is based on the interaction among the actors: "The complex interactions and communications of policy-making are themselves part of the outcome, as they change the participants and the participants' actions and reactions." ${ }^{38)}$

Finally in the spring of 2007, protest movements over the possible effects linked to radiation led the municipality to suspend the project. In December, it proposed limiting the train's speed in residential zones and announced a new course of action after a two-week consultation. These changes illustrate the ability of citizen's groups to influence planning measures. The NIMBY syndrome faced by the Maglev project indicates the emergence of an urban middle class with the capacity to grasp the stakes in development and to mobilise itself to influence projects. It is worth noting that protests were especially large in the Minhang area, a new suburb of white-collar residents in Shanghai's south.

More than a year after the protests, the project remains moribund. It's possible to put forward the hypothesis that in a collaborative context, citizens' mobilisation would help reach a compromise and realise the project. However, the project's financial cost is often cited as a reason to suspend work. From this viewpoint, the authorities could hide behind the desire to respond to residents' opposition in order to review the contract with the Germans. From this perspective, the collaborative influence on Shanghai's urban planning practices would be quite illusory.

\section{Illusion of collaborative ideal}

Whatever the semantic formula adopted, there is consensus on the fact that the communicative or collaborative approach is now the dominant paradigm in urban planning theory. ${ }^{(39)}$ However, the Chinese experience with the Maglev shows the same limits that Western practices have faced in matters of urban planning with an as yet nascent collaborative current ${ }^{(40)}$ in which NIMBY-style protests are often the only chance for citizens to influence redevelopment decisions.

In fact, town planning is often the preserve of a small circle of actors who can be characterised as the elite. The urban regimes model developed by Clarence Stone ${ }^{(41)}$ based on Atlanta's case shows that urban management often consists of a balance between public and private actors. Shanghai's situation seems to resemble the North American model. With the emergence of new openings to the private sector and civil society in the Party apparatus, a socialist pro-growth coalition has been taking shape. However, this movement is limited to the elite:

Despite the immense differences between $\mathrm{Hu}$ and Jiang, the younger supremo has largely incorporated the Third-Generation leader's 'Three represents theory' (san ge daibiao). This unorthodox theory was used by Jiang in 2001 to absorb elements within the "new classes" - such as private businessmen, professionals and haigui pai or well-trained "returnees" from abroad - into the CCP. The unstated reason offered by Jiang and $\mathrm{Hu}$ is that only well-educated, IT-savvy citizens - and not barely literate peasants or migrant workers - are capable of bringing the "the highest productivity and the most advanced culture" to the Party and China. ${ }^{(42)}$

The illusion of the collaborative ideal in Chinese urban planning can be seen in the exclusion of the mingong (migrant workers from rural areas) from planning forums. Although they are the bulwarks of development in the city, they are largely marginalised and are denied the rights other Shanghainese enjoy. Apart from the potentially explosive aspects, this situation points to the need to open local governance systems, ${ }^{(4)}$ without which no genuinely harmonious planning can take place.

\section{Harmonious urbanisation: Emergence of a Chinese ap- proach to planning?}

Observation planning practices show diverse theoretical references. Apart from the possible gap between theory and

38. Judith E. Innes, "Information in Communicative Planning," in Journal of the American Planning Association, vol. 64, n¹, 1998, pp. 52-63.

39. Judith E. Innes, "Planning Theory's Emerging Paradigm: Communicative Action and Interactive Practice," in Journal of Planning Education and Research, vol. 14, n³, 1995 pp.183-190. Ernest R. Alexander "A Mile or a Millimeter? Measuring the 'planning theory-practice gap'," in Environment and Planning B: Planning and Design, vol. 24, 1997, pp. 3-6. Allmendinger, 2002, op. cit.

40. Nicolas Douay, La planification urbaine à l'épreuve de la métropolisation: Enjeux, acteurs et stratégies à Marseille et à Montréal (Urban planning tested by metropolisation: Issues, actors, and strategies in Marseille and Montreal), Montréal \& Aix-en-Provence, Université de Montréal - Université Paul Cézanne (Aix-Marseille), doctoral thesis in city and regional planning, 2007.

41. Stone, 1989 , op.cit

42. Willy Wo-Lap Lam, "Chinks in the armour of Hu Jintao: Can a harmonious society emerge in the absence of political reform?" in China Perspectives, 2007, $n^{\circ} 3$, pp. 4-11.

43. Tingwei Zhang, "Decentralization, Localization, and the Emergence of A Quasi-Participation Decision-Making Structure in Urban Development in Shanghai," in International Planning Studies, vol. 7, n4, 2002, pp. 303-323. 
practice, ${ }^{(44)}$ different theoretical currents correspond to planning styles that often interact or even clash with each other. ${ }^{(45)}$ Shanghai's example shows the persistence of a traditional practice of planning, with the issue of regulating the use of land remaining central. Renovation is expressed through the strategic influence corresponding to the city's economic opening and the formation of a socialist progrowth coalition. However, as in Western metropolises, the collaborative current is still new, with issues of democratisation remaining to be addressed. Apart from these influences, a question arises as to the originality of China's urban planning measures. In other words, is a Chinese model of urban planning being formulated?

\section{Sustainable development as a new refer- ence point for public action}

China is no exception to the global trend towards sustainable development. ${ }^{(46)}$ Thus, during the adoption of the $11^{\text {th }}$ Five Year Plan (2006-2010), the National People's Congress stressed the qualitative aspect of economic growth, especially the social and environmental aspects. The plan foresaw a new model of economic development based not on growing consumption of resources but on their more efficient use. The plan stressed the responsibility of the authorities to implement these objectives. ${ }^{(47)}$

The formulation of a Chinese model of urban planning could thus benefit from the concept of harmonious development, which could make for a synthesis between the Chinese approach and different Western influences. In metropolitan Shanghai, the Dongtan eco-city has focused local and international attention on what seems like a governmental window in this matter.

\section{Dongtan: Government's sustainable and harmonious window}

Dongtan is a project for an ecological city that, like the Maglev, is planned to open in time for Expo 2010. The eco-city will be built on Chongming Island, at the mouth of the Yangtze River north of Shanghai. Covering $86 \mathrm{~km}^{2}$, the city will initially have between 50,000 and 80,000 inhabitants, but the number is expected to rise to 500,000 by 2050 .

Facing energy shortages and recurring pollution problems, China will use Dongtan as a test site for building an eco-city as it has been conceived right from the start. This would help put in place in a big way all the latest technical and town planning innovations for producing green energy, insulation, and traffic. It will be built in the middle of a swamp. British firm Arup has undertaken to plan the new city drawing on the experience of the English eco-city, Bedzed (Beddington Zero Energy Development). Situated in the suburb of London, Bedzed eschews fossil fuels and thus $\mathrm{CO}^{2}$ emissions.

However, the Shanghai plan has attracted much criticism. Vast swampy areas in the southeast of the island are classified as an internationally protected nature reserve. Its location on the route of rare migratory birds (especially the Black-faced Spoonbill) has caused the site to be contested on conservation grounds. Academics at the College of Urban Planning in Shanghai's Tongji University questioned the wisdom of choosing the site when there was land left to develop in the Pudong and Nanhui districts east of Shanghai. The college's director, Zhao Min, said: "I'm against this project, like most of my colleagues here." ${ }^{(48)}$ Criticism is focused on the drainage system to be built, as well as the complexity of the foundations. Moreover, experts point out that the ecological footprint of the project is huge (2.2 hectares per head), that there is no real social mix, and that transport to central Shanghai will be inadequate.

The plans were drawn up in 2005 and work was to begin in late 2006, but the project has yet to take off. Dongtan is touted as the environmental window of Chinese town planning, but up to now the eco-city has yet to evoke real enthusiasm or emerge as a model that can be replicated in other provinces. If even a part of the city is built before the start of Expo 2010, the authorities could hold it up as an example of harmonious town planning and draw attention away from the real challenges of sustainable urban development.

\section{Conclusion: Harmonious urbanisation as new paradigm?}

Even though the traditional planning model is still largely present, strategic, collaborative and environmental influences help envisage the formulation of new practices for Chinese town planning. ${ }^{(49)}$

44. Alexander, 1997, art. cit.

45. Innes et al., 2005, art. cit.

46. "Sustainable development," as defined by the World Commission on Environment and Development: "Development that meets the needs of the present without compromising the ability of future generations to meet their own needs. It contains within it two key concepts; the concept of 'needs,' in particular the essential needs of the world's poor, to which overriding priority should be given; and the idea of limitations imposed by the state of technology and social organizations on the environment's ability to meet present and future needs."

47. OECD, Environmental Performance Reviews: China, Paris, OECD, 2007.

48. http://www.chine-informations.com/actualite/chine-dongtan-ecocity-une-ville-100ecologique-pres-shanghai_6180.html, (visited 2 November 2008). 
Given the sustainable development concept that has become inescapable today, at least in public discourse, a synthesis of the main currents has been formulated through the concept of harmonious town planning, which could become a new Chinese paradigm in this field.

The idea of harmonious society was advanced as a new objective in 2004 during the fourth plenary session of the $16^{\text {th }}$ Communist Party Central Committee. In matters of development, the concept is rendered as harmonious urbanisation. Moreover, following Nairobi (2002), Barcelona (2004), and Vancouver (2006), Nanjing hosted the $4^{\text {th }}$ World Urban Forum of the United Nations in November 2008, with the theme "Harmonious urbanisation: The challenge of balanced territorial development." ${ }^{(5)}$ The event was in line with the theme of Expo 2010.

The characteristics of this Chinese approach to planning take account of inputs from Western theories, but leave open some questions as to the actual harmonious nature of Chinese cities.

In terms of economic harmony, the strategic current helps meet the challenges of globalisation by ensuring the growth and development of cities. But many questions remain unanswered as to the proper functioning of the market mechanism, especially as regards real estate and property.

As for environmental harmony, the sustainable approach leads to new solutions, especially the as-yet improbable ecocities, to meet the challenges of climate change, but apart from the various models that may be put forward, the planning process would have to face the challenges of cities as they are now. Thus, given the dimensions of the urbanisation dynamic, there is a need for special attention to the protection of natural and agricultural resources. ${ }^{(52)}$ Also, the modernisation of urban areas should also respect architectural and urban heritage. In more general terms, development and reconfiguration of cities must not neglect some spaces, especially the fringes of metropolises, so as to avoid heightening spatial polarisation.

When it comes to social harmony, the collaborative current helps respond to citizens' actions, be it of the NIMBY variety or more general demands for participation in the planning process. However, the emergence of a collaborative approach raises the question of social inequality and gives rise to demands for political reform. The development of metropolises is almost inevitably accompanied by the deepening of social inequalities. The question of social polarisation pertains mainly to the millions of marginalised mingong. Moreover, the displacement of population in the name of real estate development projects ${ }^{\left({ }^{(3)}\right)}$ leads to numer-

\section{The concept of harmonious urbanisation ${ }^{(50)}$}

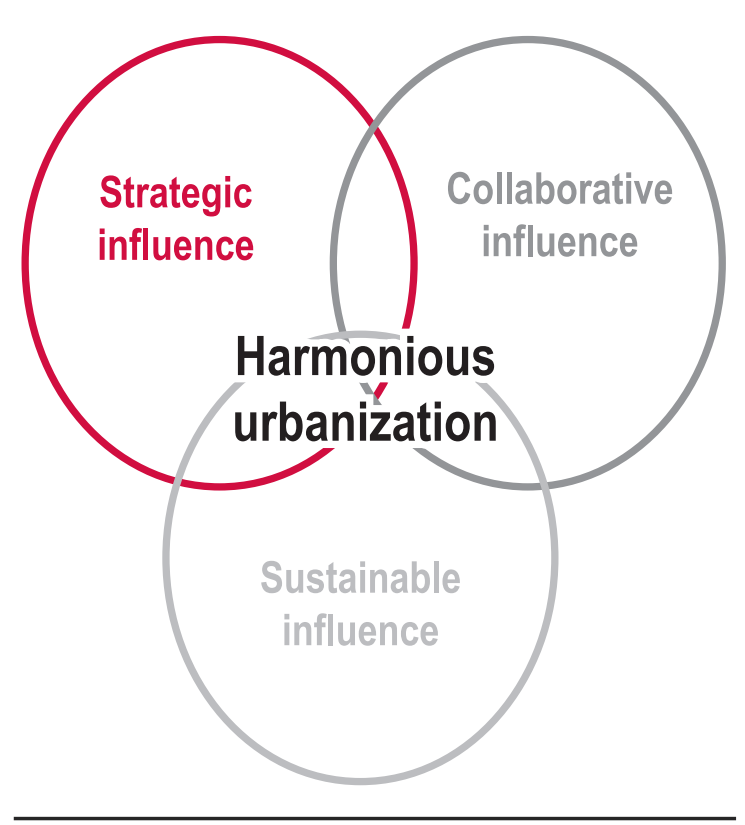

ous expropriations, which are often the source of major conflicts. In the context of rising property speculation, many new residences remain vacant, with former residents or even the mingong who built them in the first place being barred from occupying them. In these conditions, the logic of socio-spatial polarisation ${ }^{(54)}$ could become explosive if it continues to be ignored. In more general terms, the construction of a harmonious society supposes the development of new democratic mechanisms. It is possible to imagine that "the CCP leadership will play the role of a 'mediator' and 'balancer' among the interests and aspirations of disparate socio-economic groupings," (55) but only the organisation of free elections or the emancipation of residents' com-

49. Yanhong Kang et al., "Reconsideration of Humanistic Urban Planning," in China City Planning Review, vol. 16, n²1, 2007, pp. 16-21.

50. This figure depicts sustainable development, but if the Chinese concept of harmonious urbanisation borrows from this model, it would not be a straight copy.

51. www.unhabitat.org

52. Erik Lichtenberg et al., "Assessing Farmland Protection Policy in China » in Y. Song et al., Urbanization in China: Critical Issues in an Erea of Rapid Growth, Cambridge, Lincoln Institute of Land Policy, 2007, pp. 101-116. Robert Ash, « Managing China's Arable Land Resources in an Era of Sustainability » in Y. Song et al., Op Cit, 2007, pp.117-141.

53. Valérie Laurans, "Shanghai: Modern Conveniences as an Argument for Displacing Residents," in China Perspectives, n58, 2005, pp.10-21.

54. Guillaume Giroir, "Socioterritorial Fractures in China: The Unachievable "Harmonious Society"?, in China Perspectives, $n^{0} 3,2007$, pp. 83-91.

55. Wo-Lap Lam, 2007, art. cit. 
mittees would facilitate genuine citizen participation in planning mechanisms.

The passage from theory to practice with the advent of this harmonious urbanisation idea poses many challenges linked to the subtle relationship between theory and practice: "Theories are tools that mask as much as they reveal." ${ }^{(56)}$ Theories are often built on the basis of practice while seeking to advance changes in them, and practice for its part benefits from theories that are further developed in the process. In China's urban planning, theoretical influences on practice occur through the concept of harmonious urbanisation, but the burgeoning problems reveal the gap between theory and practice. In conclusion, the consistency of this concept is called into question: does it correspond to the formulation of a Chinese paradigm, or merely offer new words to mask the persistence of traditional practices? In fact, in the context of another emerging, rapidly growing country, Mike Davis ${ }^{(57)}$ has shown that at Dubai the traditional approach characterised by strong rationality is still current. The official ideology of harmonious urbanisation will henceforth be tested by massive urbanisation, and this presents a major challenge for Chinese urban planning, because in the absence of harmonious cities a harmonious society is unlikely to come about.

\section{- Translated by N. Jayaram}

